

\title{
Analysis of the educational potential of a science museum learning environment: visitors' experience with and understanding of an immersion exhibit
}

Marianne Foss Mortensen

\section{- To cite this version:}

Marianne Foss Mortensen. Analysis of the educational potential of a science museum learning environment: visitors' experience with and understanding of an immersion exhibit. International Journal of Science Education, 2010, pp.1. 10.1080/09500691003754589 . hal-00602614

\section{HAL Id: hal-00602614 https://hal.science/hal-00602614}

Submitted on 23 Jun 2011

HAL is a multi-disciplinary open access archive for the deposit and dissemination of scientific research documents, whether they are published or not. The documents may come from teaching and research institutions in France or abroad, or from public or private research centers.
L'archive ouverte pluridisciplinaire HAL, est destinée au dépôt et à la diffusion de documents scientifiques de niveau recherche, publiés ou non, émanant des établissements d'enseignement et de recherche français ou étrangers, des laboratoires publics ou privés. 


\title{
RESEARCH REPORT
}

\section{Analysis of the educational potential of a science museum learning environment: visitors' experience with and understanding of an immersion exhibit}

\begin{abstract}
Research pertaining to science museum exhibit design tends to be articulated at a level of generality that makes it difficult to apply in practise. To address this issue, the present study used a design-based research approach to understand the educational potential of a biology exhibit. The exhibit was considered an educational environment which embodied a certain body of biological knowledge (Biological Organization) in a certain exhibit type (Museographic Organization) with the intention of creating certain learning outcomes among visitors. The notion of praxeology was used to model intended and observed visitor outcomes, and the pattern of relationship between the two praxeologies was examined to pinpoint where and how divergences emerged. The implications of these divergences are discussed at the three levels of exhibit enactment, design, and conjecture, and theoretically based suggestions for a design iteration are given. The potential of the design-based research approach for educational exhibit design is argued.
\end{abstract}

\section{Introduction}

Barring a few notable exceptions (e.g. Schauble \& Bartlett, 1997; Falcão et al., 2004; Guichard, 1995), current research pertaining to the design of informal educational interventions such as science museum exhibits contributes mainly to an accumulation of general recommendations and design guidelines. Examples of such guidelines from the last three decades are the findings that computer-based exhibits engage visitors (Meisner et al., 2007), that partially completed exhibit puzzles are more motivating for children than fully completed or uncompleted puzzles (Henderlong \& Paris, 1996), and that visitors are attracted by exhibits that impart a short clear message displayed in a vivid manner (Alt \& Shaw, 1984). While these findings are no doubt both reliable and valid, the design principles derived from them are articulated at a level of generality which makes them difficult to refute, and can accordingly inform museum exhibit engineering only superficially (Moscardo, 1996). Further, the general nature of the design principles makes them unable to account for the influence of contexts and the emergent nature of outcomes 
(Robinson, 1998); yet the phenomena that emerge from the context and its interaction of numerous factors are 'precisely what educational research most needs to account for in order to have application to educational practice’ (The Design-Based Research Collective, 2003, p. 6).

The present study takes a design ${ }^{1}$-based research approach to exhibit engineering. In this perspective, the science museum exhibit is considered an embodiment of specific theoretical claims about teaching and learning (The Design-Based Research Collective, 2003); an embodiment which may be refined by investigating and connecting processes of its enactment (the outcomes of visitors' interactions with the exhibit) to aspects of its design and thus back to the conjecture which drives the design (Sandoval, 2004). The embodiment and enactment of these specific theoretical claims are examined as a way to not only improve the designed intervention - the exhibit - but also as a way to pinpoint contextual features that may improve the understanding of the underlying learning processes targeted by the design. Thus, rather than testing that the intervention works, the question is how it works (Sandoval, 2004).

Aim

The aim of the present study is to investigate the relationship between the design of a museum exhibit and the subsequent visitor interactions with and understandings of that exhibit, using the stated learning objectives for the exhibit as a measure of how well the exhibit performs. The stated learning objective of the exhibit may accordingly be thought of as its theoretical claim about teaching and learning, the exhibit itself as the embodiment of that claim, and the visitor interactions and understandings as the enactment of the claim.

\section{Theory and Application}

\section{The Notion of Praxeology as an Analytical Framework}

A praxeology is a general model which links the practical dimensions (the practice) and the theoretical dimensions (the theory) of any commonly occurring human activity (Barbé et al., 2005). The simplest praxeology (Figure 1) consists of a task of some type which is perceived by the learner and accomplished using a corresponding technique. The technology is the learner's rationale or justification for the chosen technique - why does it work, where does its effectiveness come from? - and finally, the theory refers to a more abstract set of concepts and arguments arranged into a general discourse which justifies the technology itself (Chevallard, 2007). An example from thirdlevel biology education may serve to illustrate the model (Figure 2). 


\section{Theory}

\section{Technology}

\section{Technique}

\section{Type of Task}

Figure 1. A praxeology, consisting of a type

of task, a technique, a technology and a

theory.

The practice block of a praxeology consists of the task and the technique components, and may be thought of as 'know-how', while the theory block, consisting of the technology and the theory, may be thought of as 'know-why'. Praxeologies may occur in larger systems in which several practice blocks are explained by one theory block; a collection of practice blocks that share the same technology and theory is called a local organization (Chevallard, 1999). Expanding the example of a praxeology provided in Figure 2 to a local organization could entail including a second task, for example one that dealt with dihybrid crosses. The technique used to accomplish this second task would be different from the technique used to solve the first, yet can be explained using the same technology (and theory) as the first task. 




Figure 2. An example of a praxeology. A learner is given the following question: 'if a monohybrid cross was carried out between two pea plants, both of the phenotype 'tall' and genotype Tt, what would be the expected ratio of the phenotypes of the resulting offspring?' The task perceived by the learner in this case could be expressed as: 'find the ratio of tall plants to short plants in the group of plants produced by crossing a Tt plant with a Tt plant'. The technique with which the learner could do this is by constructing a Punnett square - a diagram to predict the outcome of any breeding experiment - resulting in the present case in the offspring genotype ratio of $1 \mathrm{TT}: 2 \mathrm{Tt}: 1 \mathrm{tt}$. The technology, or justification of the use of the Punnett square, is that each of the parent plants produces gametes with just one of the two alleles for each trait. Because the parent plants are both genotype $\mathrm{Tt}$, they can produce gametes containing either the $\mathrm{T}$ allele or the $\mathrm{t}$ allele. Fertilisation entails the fusion of one maternal gamete with one paternal gamete resulting in one of the four genotypes shown in the Punnett square (TT, $\mathrm{Tt}$, or $\mathrm{tt}$ ). Because the dominant allele (denoted by the capitalised letter $\mathrm{T}$ ) is always expressed, the resulting phenotypes of the offspring are, on average, 3 tall pea plants ( $\mathrm{TT}+\mathrm{Tt}+\mathrm{Tt}$ ) to 1 short pea plant (tt). The theory of the praxeology exemplified here entails a broader understanding of genetics, including the facts that the Mendelian ratio of 3:1 is a theoretical prediction that assumes segregation and independent assortment of alleles, and that there are situations where these assumptions are not met, for example when alleles are co-dominant or when there are interactions between alleles of different genes. 
Any body of knowledge may be thought of as a praxeology or family of praxeologies the acquisition of which corresponds to the mastery of the practice and theory components of the knowledge. The praxeology model has been used as a framework for the analysis and design of teaching interventions in formal science education settings where its most important contribution has been the identification and remediation of disassociations between the practice and the theory of taught bodies of knowledge; disassociations that originated at the curriculum level and which precluded students from gaining any deeper understanding of the bodies of knowledge in question (e.g. Barquero et al., 2007; Rodríguez et al., 2007). The strength of the notion of praxeology is thus its ability to link the characteristics of taught bodies of knowledge with the characteristics of learnt bodies of knowledge, or, as outlined by Sandoval (2004), to connect processes of the enactment of a teaching intervention to aspects of its design and thus back to the conjecture which drives this design.

In the present study, the notion of praxeology is used in an analysis of the teaching environment that is the museum exhibit. The intended praxeology embodied by a museum exhibit is elucidated and compared with the observed praxeology of visitors to the exhibit. The emergent patterns of difference between these praxeologies will make possible the assessment and subsequent refinement of the conjecture embodied by the exhibit as a means of supporting a specific educational objective among museum visitors. In other words, the approach will yield theoretically grounded and practically applicable principles for improving the alignment of exhibit conjecture, design, and educational outcomes.

\section{The Exhibit and its Intended Praxeology}

The studied exhibit is part of the travelling exhibition 'Xtremes' which opened in October 2007 at Experimentarium, a science centre in Copenhagen, Denmark and in October 2008 at the Royal Belgian Institute of Natural Sciences (RBINS) in Belgium. The general theme of Xtremes is animal adaptations to extreme environmental conditions on Earth and it features five clusters: Heat, Cold, Aridity, Low Oxygen, and Darkness, respectively. The attention here is to a single immersive exhibit, 'Cave Expedition', within the cluster about darkness. The exhibit is described in detail in Mortensen (2009).

The design process of Cave Expedition integrated a biological body of knowledge with a chosen exhibit style or strategy (Mortensen, 2009). Translated into praxeology terminology, the process deconstructed and reconstructed a biological body of knowledge (or Biological 
Organization) by means of an exhibit strategy (or Museographic Organization). The Biological Organization embodied by Cave Expedition is the adaptations of the blind cave beetle to its environment of permanently dark caves, and the means by which this Biological Organization is embodied is the Museographic Organization of an immersion exhibit. Immersion is a specialised exhibit practice in museums, defined by the creation of an illusion of time and place through the reconstruction of key characteristics of a reference world, and by integrating the visitor in this reconstructed world (Bitgood, 1990). The successful reconstitution of the reference world relies on the presentation of the exhibit as a coherent whole, the integration of the visitor as a component of the exhibit, and the consequent dramatisation of matter and message (Belaën, 2003).

In Cave Expedition, the integral components of the Museographic Organization are the reconstruction of the cave beetle's habitat in the form of an artificial, scaled-up cave containing representations of key characteristics of the cave beetle's habitat; the bestowing of the role of the cave beetle to the visitor through interpretive signage; and finally, the interaction between the visitor in their role as a cave beetle and the reconstructed cave beetle habitat which potentially creates a discourse which dramatises aspects of the cave beetle's daily struggle for survival (Mortensen, 2009). These key components of the Museographic Organization together represent the Biological Organization, resulting in a multiply embodied learning ecology which functions as a whole rather than as a collection of activities or separate factors that operate in isolation from one another (Cobb et al., 2003; Sandoval, 2004). For the purposes of analysis, these activities are defined and operationalised in the praxeology framework in the following.

A praxeology is defined by its component task or tasks. The exhibit Cave Expedition consists of a number of different types of tasks that may be accomplished using different techniques, e.g. interpretive panels to be read, an artificial cave to be navigated, etc. The first observation that may be made is that the intended praxeology of the exhibit encompasses more than one practical block. Further, the intended visitor outcome of the exhibit is to enable the visitor to find out, through their experiences, how the cave beetle is adapted to its environment of permanently dark caves (Executive Committee, 2005). This outcome frames the tasks and techniques embodied by the exhibit, and may thus serve as the unifying technology of the exhibit. The second observation that may be made is accordingly that the intended praxeology of the exhibit is of the type: local organization. The theory component of such a local organization may or may not encompass several local organizations; in the present case, the theory is located at the level of the entire exhibit cluster 'Darkness' and will consequently not be considered further here. 
The tasks embodied by Cave Expedition were induced and defined by their role in the Museographic Organization. For example, the first task was embodied by Panel 1 and its text and illustration (Figure 3). This panel embodies the visitor task of perceiving that the cave beetle's adaptations include elongated legs, elongated antennae, reduced eyes, and enhanced senses of smell, taste and touch. The technique to accomplish this task is reading the text and discerning the variations in the traits of the depicted beetles. Another task is embodied in Panel 2 and its text, which reads:

\section{Cave Expedition.}

Wait for the light to turn green and go into the cave.

Return to the darkness.

Feel the walls, find the animals, smell the odours.

When you are outside, identify your findings.

Panel 2 embodies the visitor task of perceiving and accepting their intended role as the cave beetle, and this task may be accomplished by reading the text which requests the visitor to enter the cave and feel the walls, find the animals, and smell the odours, at the same time referring to Panel 1 where these behaviours were described as cave beetle characteristics. 


\section{At home in the dark}

Living in caves where it is permanently dark, the blind cave beetle has developed senses other than sight. It has much longer legs and antennae than related species which live above ground, increasing the area available for receptors for smell, touch, and taste, which enable it to find its way around - as well as to choose its next meal.
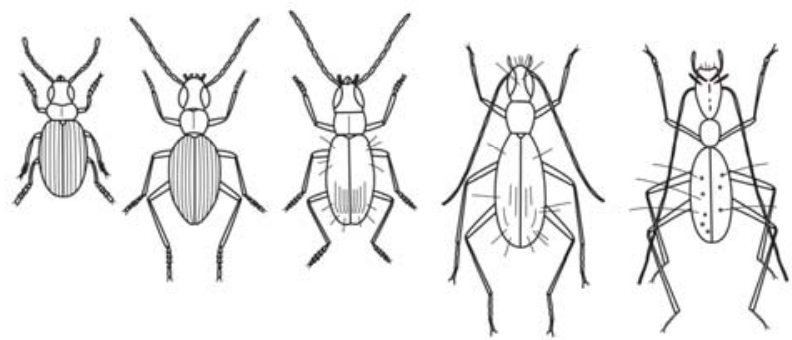

Series of cave-dwelling beetles (Carabidae) with different forms of adaptation to their environment. Left: above ground.

Right: underground.

Figure 3. Panel 1 in Cave Expedition consisted of an introductory text, an illustration, and a caption in roughly the proportions shown. Beetle illustration (c) 2007 by RBINS, Experimentarium, and Naturalis. Reprinted with permission.

A final example of a task embodied by Cave Expedition is the external and internal structure of the artificial cave. The artificial cave is constructed from an uneven, grey, rocklike material and has a completely darkened interior; these characteristics embody the visitor task of perceiving the exhibit as a representation of a cave. The technique with which this task may be carried out is the visitor's recognising the characteristics of the artificial cave as 'cave-like'. The complete intended praxeology of Cave Expedition, eight tasks and their corresponding techniques and technology, is shown in Table 1. 
Table 1. The intended praxeology of the exhibit Cave Expedition, expressed in terms of tasks, techniques, and technology.

\begin{tabular}{|c|c|c|c|}
\hline Task & Embodied by & Technique & Technology \\
\hline $\begin{array}{l}\text { Perceive that cave beetle } \\
\text { adaptations include: elongated } \\
\text { legs, elongated antennae, } \\
\text { reduced eyes, enhanced senses } \\
\text { of smell, taste, and touch }\end{array}$ & Panel 1 text and illustration & $\begin{array}{l}\text { Discern variation in beetle } \\
\text { features in illustration; read } \\
\text { text }\end{array}$ & \multirow{8}{*}{$\begin{array}{l}\text { Interpret own role to be an } \\
\text { analogy of the cave beetle's, } \\
\text { interpret own actions to be } \\
\text { analogies of those of the cave } \\
\text { beetle's, interpret exhibit } \\
\text { features to represent } \\
\text { characteristics of cave beetle } \\
\text { habitat. Thereby experiencing } \\
\text { vicariously and understanding } \\
\text { that the cave beetle's habitat is } \\
\text { characterised by being dark } \\
\text { and enclosed; that the beetle } \\
\text { navigates using touch, not } \\
\text { vision; that there are other } \\
\text { cave-dwelling animals in the } \\
\text { cave beetle's habitat and that } \\
\text { the cave beetle may discern } \\
\text { these by touch. }\end{array}$} \\
\hline $\begin{array}{l}\text { Perceive intended visitor role } \\
\text { as cave beetle }\end{array}$ & Panel 2 text & $\begin{array}{l}\text { Identify instructions on panel } \\
2 \text { as pertaining simultaneously } \\
\text { to how to proceed and to cave } \\
\text { beetle behaviour }\end{array}$ & \\
\hline $\begin{array}{l}\text { Perceive exhibit as } \\
\text { representation of cave habitat }\end{array}$ & $\begin{array}{l}\text { External and internal cave } \\
\text { structure }\end{array}$ & $\begin{array}{l}\text { Recognise characteristics of } \\
\text { exhibit as cave-like }\end{array}$ & \\
\hline $\begin{array}{l}\text { Assume role of cave beetle by } \\
\text { assuming its adaptations }\end{array}$ & $\begin{array}{l}\text { The internal cave structure and } \\
\text { the transition from the outside }\end{array}$ & $\begin{array}{l}\text { Switch sensory modalities } \\
\text { from primarily vision to touch } \\
\text { and smell (induced by } \\
\text { darkness and odour in } \\
\text { exhibit) }\end{array}$ & \\
\hline $\begin{array}{l}\text { Perceive that cave beetle } \\
\text { movement is dictated by cave } \\
\text { habitat's physical boundaries }\end{array}$ & $\begin{array}{l}\text { The configuration of the } \\
\text { passageway inside the cave } \\
\text { structure }\end{array}$ & $\begin{array}{l}\text { Use touch to assess } \\
\text { boundaries, proceed } \\
\text { accordingly }\end{array}$ & \\
\hline $\begin{array}{l}\text { Perceive that cave beetle } \\
\text { heterospecifics co-inhabit the } \\
\text { cave habitat }\end{array}$ & $\begin{array}{l}\text { Animal models mounted on } \\
\text { internal wall of exhibit }\end{array}$ & $\begin{array}{l}\text { Discern and identify animal } \\
\text { models as cave inhabitants by } \\
\text { touch }\end{array}$ & \\
\hline $\begin{array}{l}\text { Perceive that cave beetle } \\
\text { habitat may be characterised } \\
\text { by odours }\end{array}$ & Presence of odour in exhibit & $\begin{array}{l}\text { React to odour gradient from } \\
\text { outside to inside of cave } \\
\text { structure }\end{array}$ & \\
\hline $\begin{array}{l}\text { Assess own ability to survive } \\
\text { the daily conditions for a cave } \\
\text { beetle }\end{array}$ & Panel 3 text and scoreboard & $\begin{array}{l}\text { Compare visible animal } \\
\text { models with memory of } \\
\text { models inside cave structure; } \\
\text { compare scents with memory } \\
\text { of scent inside cave structure }\end{array}$ & \\
\hline
\end{tabular}

\section{Data Collection and Analysis}

Data were collected from three discrete groups of visitors designated as pilot visitor groups, casual visitors, and respondents, respectively (Table 2). The pilot visitor groups were observed and interviewed at Experimentarium in Copenhagen in August 2008 and the casual visitors and respondents were observed and/or interviewed at RBINS in Brussels in February and March 2009. The layout and content of the exhibits comprising Xtremes were identical in the two locations barring a few instances which were unrelated to the cluster Darkness. All data were collected in the immediate vicinity of Cave Expedition. Interviews were conducted in Danish at Experimentarium and in English at RBINS. Some informants at RBINS responded to the questions or the think aloud 
(explained in the following) in their native language, thus of the 16 respondents, 5 responded entirely or partially in French, and 5 responded entirely or partially in Flemish. The audio recordings of these respondents were transcribed and translated into English by native French and Flemish speakers, respectively. The audio recordings of the informants responding in English or Danish were transcribed (and translated into English in the latter case) by the author. All data was collected during school holidays.

Table 2. Details of informants. No informant participated in more than one group.

\begin{tabular}{|c|c|c|c|c|}
\hline Participant type & $\mathbf{n}$ & Designation & Location & Treatment \\
\hline Pilot visitor groups & 20 & P001 - P020 & Experimentarium & Observation, interview \\
\hline Casual visitors & 100 & C001-C100 & $\begin{array}{l}\text { Royal Belgian } \\
\text { Institute of Natural } \\
\text { Science }\end{array}$ & Observation \\
\hline Respondents & 16 & R001 - R016 & $\begin{array}{l}\text { Royal Belgian } \\
\text { Institute of Natural } \\
\text { Science }\end{array}$ & Observation, think aloud, interview \\
\hline
\end{tabular}

\section{Pilot Study}

The basic idea of the design-based research approach is that it responds to emergent features of the educational setting (The Design-Based Research Collective, 2003). In order to gain an initial understanding of this setting (i.e. the visitors' interactions with the exhibit) and what might constitute emergent features, a pilot study was conducted. Family groups, i.e. groups consisting of at least one adult and one to three children, were designated as the target pilot visitor demographic. Visitor groups which fulfilled these requirements were discreetly observed during their approach to the exhibit, and when the second member of the group crossed an imaginary line on the floor, the observer formally started the observation. If they continued past the exhibit, the timing was stopped and the group not included in the study. If they navigated through the exhibit (the criterion for inclusion in the pilot study), they were observed during their interaction with the exhibit. Their behaviour inside the cave was observed via an infra-red closed circuit TV installed for safety purposes and publically viewable outside the exhibit. Their path through the exhibit area was traced on a floor map. Upon their leaving the exhibit, as gauged by the second member of the group crossing an imaginary line on the floor, the observer stopped the time-taking and approached them to request a brief interview. Consenting groups were interviewed, and the entire exchange recorded 
on a digital recorder. Gender and approximate age of each group member were recorded. A total of 20 groups, designated as P001 through P020, were observed and interviewed.

Interview questions.

The initial interview questions were formulated on the praxeology-based idea that the engagement between the visitor and the exhibit had two aspects: a practical and a theoretical aspect. The practical aspect consisted of visitors' direct interactions and experiences with the exhibit and could be investigated through direct observations and interview questions; the theoretical aspect consisted of visitors' reflections about and explanations of these direct experiences and could be made tangible through interviews. The interview questions were consequently formulated at two levels: a basic level to probe the visitors' direct (and when possible, observed) interactions with the exhibit, and at a higher level to elucidate how these interactions were interpreted. Consider the following example:

1. What is it supposed to be, the exhibit you were just exploring?

A majority of pilot visitor groups answered 'a cave', which led to the second question:

2. What makes it a cave, in your opinion?

Question 1 is a basic-level question intended to focus the visitors' attention on an exhibit feature (the artificial cave); question 2 attempts to discover why the visitors interpret the exhibit feature in question as they do. Question 1 was considered practical-level question; question 2 a theoretical-level question. Another example of a theoretical-level question is the following:

8. What is the point of this exhibit? What are you meant to learn from it or do with it?

Questions of this level were intended to probe how the visitors integrated their exhibit experiences into a coherent whole.

The interview questions underwent two sets of revisions during the 12 days in which the pilot study took place, once after the first five interviews (P001-P005) and again after the next five interviews (P006-P010). These revisions were based on the previous observations and visitor responses and consisted of clarifications of the questions in order to focus more precisely on the visitors' experiences with and subsequent interpretation of the exhibit. For example, question 2 in the above example was formulated after the second revision and accordingly only applied to groups P011-P020.

Outcomes of the pilot study.

The pilot study had three outcomes that shaped the continued investigation: First, the study confirmed that the visitors' interactions with and understandings of Cave Expedition could indeed 
be described using both practical and theoretical aspects. This led to the choice of the praxeology as an analytical tool for the investigation of the exhibit. Second, even though the combination of methods (observations and interviews) guided the refinement of the interview questions towards a better description of the relationship between the practical and theoretical aspects of the exhibit interaction, this relationship was not being fully captured. Specifically, there were practical aspects of the visitor-exhibit interactions that were not observable, and in the short time between their exhibit interaction and the interview, the visitors had already processed and rationalised the experience, making it part of the theoretical aspect of the exhibit visit. In other words, the visitor's memory of the experience was guided by their subsequent rationalisation of it (cf. van Someren et al., 1994, p. 21). Thus the decision was made to include the think aloud method in the further investigation (cf. Tulley \& Lucas, 1991) as outlined in the following section. Employing the think aloud method entailed a change in the target informant demographic. The use of family groups in the pilot study had been based on the best case scenario behaviour of such groups (Allen, 2002); however, the think aloud method utilises single informants (van Someren et al., 1994) and thus precluded the study of visitor groups.

Finally, the pilot study revealed that only a very small fraction of the pilot visitor groups (1 group of 20) perceived Cave Expedition to be about cave beetles. Based on this finding, it was decided to add two extra questions to the nine questions refined in the pilot study. These two additional questions were of a different nature than the first nine; in the absence of the visitors' own awareness of their role as cave beetles, these two questions would serve to inform them about this intended role and to prompt them to re-interpret on their exhibit experiences. The idea was to probe visitors' own ideas about 'what it is like to be a cave beetle' and to relate these ideas to exhibit design features. The full list of questions is listed in Appendix A.

\section{Experimental Design}

The final experimental design consisted of three data collection methods: observations, think aloud recordings, and interviews (Table 3). These three methods were chosen to cover the range of visitor educational outcomes from the practical to the theoretical level of the exhibit's intended praxeology. By covering, with an extent of overlap, the entire range of visitor outcomes specified here, the combination of methods also provides a degree of triangulation which has the potential to strengthen the findings. 
Table 3. The practical and theoretical components of the visitor's interaction with and understanding of Cave Expedition and the corresponding experimental method with which the visitor's engagement at that level was assessed.

\begin{tabular}{lcccc}
\hline Praxeology & Observations & $\begin{array}{c}\text { Think aloud } \\
\text { recordings }\end{array}$ & $\begin{array}{c}\text { Unprompted recall } \\
\text { interview }\end{array}$ & $\begin{array}{c}\text { Prompted interpretation } \\
\text { interview }\end{array}$ \\
\hline $\begin{array}{l}\text { Practical level } \\
\text { (technique) }\end{array}$ & $\checkmark$ & $\checkmark$ & $\checkmark$ & \\
$\begin{array}{l}\text { Theoretical level } \\
\text { (technology) }\end{array}$ & & $\checkmark$ & $\checkmark$ & $\checkmark$ \\
\hline
\end{tabular}

\section{Observations.}

The visitor observations had the primary goal of determining in which intended techniques visitors engaged in. For example, the task embodied by exhibit Panel 1 may be accomplished by discerning the variation in beetle features in the illustration and reading the text (Figure. 3). The minimal requirement for this task to be accomplished is for the visitor to approach and view the panel. The corresponding visitor behaviour category is thus labelled 'View Panel 1'. Another task, embodied by the animal models mounted on the internal cave wall, is accomplished by the technique of the visitor using their sense of touch to discern these models and to identify them as cave inhabitants. This technique may be partially observed using the visitor behavioural category 'Touch animals'. The procedure yielded seven behavioural categories which formed the basis of the observation study. These behavioural categories, referred to as 'behaviours', are summed up in Table 4. Two additional visitor behaviours ('View monitor' and 'Watch other visitors') were included in the visitor observations but not used in the present analysis and not considered further here. 
Table 4. Recorded visitor behaviours at Cave Expedition.

\begin{tabular}{ll}
\hline Behaviour & Description \\
\hline View Panel 1 & Visitor stands still facing Panel 1 at distance of 1m or less \\
View Panel 2 & Visitor stands still facing Panel 2 at distance of 1m or less \\
View infrared monitor & Visitor stands still with lifted head facing monitor \\
Enter cave & Visitor passes through turnstile \\
Navigate cave & Visitor proceeds through passage towards exit (observable by CC TV) \\
Touch animals & Visitor pauses with hands on animal models (observable by CC TV) \\
View Panel 3 & Visitor stands still facing Panel 3 at distance of 1m or less \\
Interact with Panel 3 & Visitor touches animal models, bends to smell scent, or presses buttons on Panel 3 \\
Watch other visitors & Visitor stands still, facing exhibit area \\
\hline
\end{tabular}

\section{Think aloud method.}

The think aloud method consists of asking informants to solve a certain problem while verbalising their thoughts, and was developed to investigate the cognitive processes that take place during problem solving (van Someren et al., 1994). The method requires the construction of coding scheme and a psychological model of the problem-solving to interpret the obtained protocols. In the present case, the method was used to provide qualitative descriptions of an exploration activity. Accordingly, a very simple verbalisation process by the informant was assumed, yielding an objective reflection of informant thought processes (cf. Dufresne-Tassé et al., 2006).

\section{Interviews.}

Open-ended interviews were conducted to explore how visitors interpreted their practical interactions with the exhibit (their techniques). The nine interview questions were finalised in the pilot study. In addition to these nine questions, two additional questions were posed to the respondents (Appendix A).

\section{Casual Visitor Study}

The casual visitor study consisted of non-intervening observations of visitors who entered a well-defined area bounded on two sides by elements of the exhibit Cave Expedition. Any adult visitor entering this area during the observation session was classified as a casual visitor, and alternate female and male subjects were observed: when the first observed casual visitor exited the observation area, the next adult of the opposite sex to enter the area became the second observed 
casual visitor, etc. The observations were carried out in half-hour sessions during the same weekdays and hours as used in the respondent study (described in the following section). The observations included recording which behaviours occurred and the amount of time spent, if any, inside the artificial cave. A total of 100 causal visitors, designated C001 through C100, were observed.

\section{Respondent Study}

In the respondent study, single adult visitors unaccompanied by children were recruited when they approached Cave Expedition. Consenting visitors were fitted with a lapel microphone connected to a wireless transmitter which fit in their pocket or clipped onto their belt. The audio feed from the microphone was transmitted to a receiver clipped on the interviewer's belt; from here it was fed to a digital Dictaphone also on the interviewer's belt. The audio feed was monitored by the interviewer using earphones plugged into the Dictaphone.

The interviewer showed the respondent the exhibit by outlining the same well-defined area as used in the casual visitor study, and asked the respondent to visit the exhibit as they normally would but at the same time vocalising their thoughts. The introduction was kept brief to minimise the degree to which respondents could form their own interpretations of the intentions of the study (cf. van Someren et al., 1994, p. 43). When the respondent turned towards the exhibit area, the interviewer began the observation. Respondent behaviour, route through the exhibit, and time spent in the artificial cave were recorded. In addition, the interviewer made notes as to the respondent's location and activities as they conducted their narration. When the respondents exited the exhibit area, they were intercepted and asked to sit down for a brief interview. The audio capture and transmission equipment stayed attached to the respondent during the interview; the lapel microphone was sensitive enough to capture the interviewer's voice as well as the respondent's. An open-ended interview was carried out using the questions listed in Appendix A. The interviewer made notes as the interview progressed to inform the subsequent questions. When the interview was concluded, the visitor was thanked and given the interviewer's contact information in case questions arose. The respondent's gender and approximate age were noted. A total of 45 visitors were asked to participate; of these 29 declined and 16 accepted. The most often stated reasons for declining was that the visitor in question didn't have time to participate, or that they didn't understand English. The sample $(n=16)$ was deemed representative of adult visitors on the basis of two findings: 1$)$ the nature of the responses given to the interview questions by respondents was relatively constant from 
respondent to respondent throughout the data collection period, and 2) a comparison of the observed behaviours of the casual visitors and of the respondents showed no significant differences, i.e. the frequency of behaviours observed in the respondents did not measurably differ from the frequency of behaviours observed in the casual visitors (nine individual $\chi^{2}$ tests, 1 d.f., $p>0.05$ in all cases).

\section{Data Analysis}

The transcripts of the think aloud and interviews were pooled for the analysis. In the first reading of the transcripts, the informants' utterances were categorised as either technique or technology and their concurrent behaviour and location noted. In the subsequent reading, the categorisation was confirmed, and emergent patterns within the two categories were noted. Specifically, the visitors' perceptions of the various tasks embodied by the exhibit emerged from this analysis. The data were analysed for both confirming and discrepant situations.

\section{The Observed Praxeology}

The observed praxeology constructed on the basis of respondent data differed in a slight but fundamental manner from the intended praxeology. The following section illustrates how the observed praxeology was created.

\section{The Observed Tasks and Techniques}

In the intended praxeology, Cave Expedition Panel 1 embodied the task of 'perceiving that cave beetle adaptations include: elongated legs, elongated antennae, reduced eyes, enhanced senses of smell, taste, and touch'. In contrast, only one of the three respondents who carried out the behaviour 'View Panel 1' made reference to these adaptations:

Here, you... it is something about insects, I think. 'Living in the caves where it is permanently dark, the blind cave beetle has developed its sense other than sight. It has much longer legs and antennae than related to species which live above the ground, increasing the area available for the receptors for smell, touch and taste which enable it to find its way around as well as to choose its next meal'. All right. Explaining, eh, this insect, and uhm, you can also see a picture of it. And where it has lived. (Think aloud, R013) 
Another respondent noted simply that the panel content pertained to beetles as illustrated in the following excerpt. The third respondent viewed but did not comment on Panel 1.

It represents some kind of bugs... beetles, they are. OK, so that explains, I guess, the... yes, OK, the blind cave beetle. OK. Well, that looks not so nice to me because I'm not so interested in bugs, but OK [laughs]. (Think aloud, R012)

While R013 read aloud the text on Panel 1, he did not verbally link the text on the cave beetle adaptations of elongated legs and antennae to the illustration of beetles which emphasise these features. Likewise, R012 did not comment on the beetle’s characteristics. Accordingly, the observed task embodied by Panel 1 may be stated as: 'Perceive text and illustration to pertain to insects, specifically, beetles'. This task is accomplished by the observed technique of reading (parts of) the text and recognising the illustration as showing beetles.

Panel 2 embodied the task 'perceive intended visitor role as cave beetle' which could be accomplished by the intended technique of identifying the text on the panel as pertaining simultaneously to how to proceed and to cave beetle behaviour. None of the ten respondents who viewed Panel 2 showed evidence of accomplishing this dual task: the text panel elicited think aloud utterances from two of them, and their perception of the text as instructions of a purely practical nature was apparent in these verbalisations:

First, [I'll] read... it is green then you can enter ... yes? (Think aloud, R006)

OK, now I am just reading the explanation: how to visit this cave... so I will wait for the green light. [...] the purpose is to feel the smell, and what kind of insects that you are finding inside this cave. That's the purpose, I think. And insects living in darkness, probably. (Think aloud, R013)

The second respondent also referred to the biological content of Panel 2, inferring that the purpose of the subsequent cave experience is to find various insects and smells in the darkness. However, R013 did not explicitly relate the assignment of finding insects and smells inside the cave to cave beetle behaviour, a disconnect which is echoed by another respondent: 
R007: Where... the kind of, little information [referring to Panel 2] just told when I could and couldn’t enter the exhibit, it didn’t tell me anything specifically about it being about a cave beetle.

The task perceived by visitors to be embodied by Panel 2 may accordingly be stated conservatively as 'enter exhibit' accomplished by the technique of 'perceive that green light indicates "enter exhibit”".

Another example of an observed task and technique is the visitors' responses to the internal and external structure of the artificial cave. The intended task embodied by these structures is 'perceive artificial cave as representation of cave beetle habitat'. Although only two respondents referred to the exhibit as a cave during the think aloud, a majority of respondents (11 of 16) stated that the exhibit was a cave when asked 'what is it supposed to be, the exhibit structure you were just visiting?', and when asked to elaborate why they perceived it to be a cave, explanations such as darkness (11 respondents), the rock-like structure (6 respondents), the appearance of the entrance (5 respondents) and the presence of models of animals associated with caves (2 respondents) were given. However, when asked whether the exhibit pertained to any particular animal, none of the respondents named the cave beetle. The following responses are typical:

R002: $\quad$ Yeah, I think, these animals that live in darkness.

Interviewer: Any particular animals?

R002: $\quad$ Just reptiles, insects, I don’t know - I haven’t seen any... what is it... bats?

R005: $\quad$ About the animals that live in the dark, I imagine.

R010: $\quad$ No, just different animals... Different animals that are living in the dark and... yeah... oh, and living under the ground.

In sum, while all respondents approached and entered the artificial cave and a majority stated that they perceived it to be a cave, none of them made reference to the cave beetle. Some respondents showed evidence of interpreting the cave from a human perspective as illustrated by the following excerpt: 
R012: $\quad$ It's also this, uhm, door maybe [refers to exhibit entrance] because sometimes you can see in the cartoons, the kind of, you know things that they made while people - at the times when they lived in the caves they made these kind of doors, so...

The observed task that may be elucidated from the data is accordingly 'perceive exhibit (from a human perspective) as representation of cave', and this was accomplished by the respondents using the technique of 'recognise internal and external characteristics of exhibit as cave-like'.

The examples shown above establish a pattern that permeated the remaining five observed tasks and techniques. While the visitors in the majority of cases responded to the exhibit tasks in accordance with the intended techniques, their fundamental perception of the tasks was from a human perspective rather than from the perspective of the cave beetle; a perception which had consequences for the nature of the technologies constructed by the respondents.

\section{The Observed Technology}

The rationales formed by the respondents as a response to their experiences with Cave Expedition ranged from a characterising their interactions with the exhibit from a purely human perspective, over the intermediate position of characterising their experiences from a human point of view and drawing parallels to animals, and finally to interpreting the exhibit as being a more or less static display about animals. In all cases where animals were mentioned, the respondents were referring to either the animals depicted in the animal models in the cave (lizards, spiders, frogs), a non-specified collection of dark-adapted animals, e.g. 'Different animals that are living in the dark and... yeah... oh, and living under the ground' (Interview, R010), or a combination of these two groups.

Examples of a purely human perspective taken in rationalising the exhibit experience are the following answers to the interview question 'What is this exhibit about? What are you meant to learn from it, or experience?':

R002: $\quad$ This experience just shows you other senses that you can rely on when you are in a different situation, just... I think that's the goal of... I think that's it. 
R008: That you don't need your sight. That you can find your way by feeling and touching things.

Six respondents took this perspective, explaining their experiences from a purely human point of view. Two respondents also took a human perspective, but in addition compared these experiences to those of dark-adapted animals when posed the above interview question:

R004: Maybe how we still function even if we don't see. And that's [what] the animals have done: adapted themselves, and we still... we could do it also.

Four respondents went further, and directly interpreted their experiences in the exhibit as analogies of those of dark-adapted animals:

R006: Oh, I think it's interesting, it's... 'cause it... it immerses us... we are like in the real... [environment]. And here, you have some sensation of the way, the animals live.

R007: Uhm, to experience what it would be like to be an animal that lived in a cave. So, it would be an animal that had adapted probably to become blind... and then using just its other senses.

Interviewer: OK? But no particular animal springs to mind?

R007: $\quad$ Uh... no.

R012: Well, I guess the experience, it's about to show you the real conditions - or at least close to real - in which those animals live in the darkness. And maybe, if you think about it, afterwards you realise that they have some senses that are much more developed than ours, because they probably could use smell or... I don't know, whatever, to find their way.

Finally, four respondents perceived the exhibit as pertaining only to animals, with no explicit link between the animals and their own experiences: 
R010: That they are living in the dark. The animals are living in the dark...

R013: I think that it is just to have a feeling how the... to feel the animals. I don't know, I... it didn’t give me so much actually. I think it will give the children more, actually. Since you have this touching and smelling thing. I think it is to underline that these animals are... that they live in darkness.

There were no discernable differences in the behaviour patterns of the visitors whose rationales fell into these different groupings. In other words, although the techniques were relatively constant from visitor to visitor throughout the sample, their technologies fell into two main categories: an exhibit-rationalised-as-experience category (twelve respondents), and a smaller exhibit-rationalised-as-static-display category (four respondents). The former technology may be conservatively described as: 'Interpret own actions to be those of human in a cave, interpret exhibit features to represent characteristics of a cave; thereby experiencing that caves are characterised by being dark and rocky, that navigation is based on touch, not vision, and that caves are inhabited by certain animals.' In some cases an additional reflection was detected, namely: 'Extrapolate own experiences in cave to those of animals inhabiting caves'. The exhibit-rationalised-as-static-display technology may be described more simply as: 'Understand that certain animal species inhabit dark environments such as caves'. The observed tasks, techniques, and technology are summed up in Table 5. For reasons discussed in the following, only the exhibit-rationalised-as-experience technology is included in Table 5.

\section{Comparing the Intended and the Observed Praxeologies}

Comparing the theoretically derived intended praxeology with the empirically derived observed praxeology reveals subtle differences at the task level that lead to a substantial divergence at the technology level, namely the respondents' failure to perceive their intended roles as cave beetles. At a first glance, it would seem that the failure of most respondents to view the exhibit's Panel 1, i.e. accomplish task 1, is at the root of the divergence. Three out of 16 respondents viewed Panel 1 (a percentage which does not significantly differ from that of the casual visitors), but these three visitors did not as a result view their subsequent experiences as those of a cave beetle, nor did they perceive the exhibit to pertain to cave beetles. Apparently, the divergence between intended and observed praxeologies had a more pervasive origin. 
Table 5. The observed praxeology of the exhibit Cave Expedition, expressed in terms of tasks, techniques, and technology. Note that the odour feature of the exhibit was out of order during the data collection; the odour-related task and technique have accordingly been omitted.

\begin{tabular}{|c|c|c|c|}
\hline Task & Embodied by & Technique & Technology \\
\hline $\begin{array}{l}\text { Perceive text and } \\
\text { illustration to pertain to } \\
\text { insects, specifically, beetles }\end{array}$ & Panel 1 text and illustration & $\begin{array}{l}\text { read (parts of) text; } \\
\text { recognise the illustration as } \\
\text { showing beetles }\end{array}$ & \multirow{7}{*}{$\begin{array}{l}\text { Interpret own actions to be } \\
\text { those of human in a cave, } \\
\text { interpret exhibit features to } \\
\text { represent characteristics of } \\
\text { a cave; thereby } \\
\text { experiencing that caves are } \\
\text { characterised by being dark } \\
\text { and rocky, that navigation } \\
\text { is based mainly on touch, } \\
\text { not vision, and that caves } \\
\text { are inhabited by certain } \\
\text { animals. }\end{array}$} \\
\hline Enter exhibit & Panel 2 text & $\begin{array}{l}\text { Identify instructions on } \\
\text { panel } 2 \text { as how to enter } \\
\text { exhibit }\end{array}$ & \\
\hline $\begin{array}{l}\text { Perceive exhibit as } \\
\text { representation of cave } \\
\text { habitat }\end{array}$ & $\begin{array}{l}\text { External and internal cave } \\
\text { structure }\end{array}$ & $\begin{array}{l}\text { Recognise characteristics } \\
\text { of exhibit as cave-like }\end{array}$ & \\
\hline $\begin{array}{l}\text { Assume role of human } \\
\text { exploring cave }\end{array}$ & $\begin{array}{l}\text { The internal cave structure } \\
\text { and the transition from the } \\
\text { outside }\end{array}$ & $\begin{array}{l}\text { Switch sensory modalities } \\
\text { from primarily vision to } \\
\text { touch }\end{array}$ & \\
\hline $\begin{array}{l}\text { Perceive that movement is } \\
\text { dictated by cave's physical } \\
\text { boundaries }\end{array}$ & $\begin{array}{l}\text { The configuration of the } \\
\text { passageway inside the cave } \\
\text { structure }\end{array}$ & $\begin{array}{l}\text { Use touch to assess } \\
\text { boundaries, proceed } \\
\text { accordingly }\end{array}$ & \\
\hline $\begin{array}{l}\text { Perceive that certain } \\
\text { animals inhabit caves }\end{array}$ & $\begin{array}{l}\text { Animal models mounted on } \\
\text { internal wall of exhibit }\end{array}$ & $\begin{array}{l}\text { Discern and identify animal } \\
\text { models as cave inhabitants } \\
\text { by touch }\end{array}$ & \\
\hline $\begin{array}{l}\text { Assess own perceptual } \\
\text { capabilities in the dark }\end{array}$ & Panel 3 text and scoreboard & $\begin{array}{l}\text { Compare visible animal } \\
\text { models with memory of } \\
\text { models inside cave } \\
\text { structure }\end{array}$ & \\
\hline
\end{tabular}

In fact, Cave Expedition was perceived to embody a human perspective rather than a cave beetle perspective in almost every aspect, not just in the perceived lack of information to this effect cited by five respondents (task 1 and 2 embodied by Panels 1 and 2). Another often cited reason was the configuration of the passageway inside the cave (five respondents) which was found to be too short, too broad, and not convoluted enough to reflect the respondents' ideas of a cave beetle's habitat. These perceived shortcomings may accordingly have obstructed the intended accomplishment of task 5 (perceive that cave beetle movement is dictated by cave habitat's physical boundaries) and substituted instead a human perception. In addition, the presence of a guide rope inside the passageway (mentioned by two respondents) and the ambient light which, while dim, was discernable (mentioned by two respondents), may have hindered the visitors' assumption of the 
adaptations of the cave beetle (task 4) and contributed instead to the perception of the exhibit as a cave in human terms.

The scaling of the exhibit was mentioned by four respondents as a reason they were not aware of their intended roles as cave beetles. Specifically, two respondents indicated that the scale of the animal models on the cave wall reflected a human perspective rather than a cave beetle:

R009: Yes, because a human is bigger than a beetle, so eh... the animals, the spider has to be bigger than us.

Accordingly, while a majority (7 of 12) of the respondents who discovered the animal models on the exhibit wall perceived them to be indicative of a cave habitat thus using the intended technique, the scaling of the animal models reinforced the human perspective and thus obscured the intended task embodied by the animal models (task 6: perceive that cave beetle heterospecifics coinhabit the cave habitat).

Finally, five respondents answered the question of why they didn't assume the role of a cave beetle in the exhibit by pointing out that the vast differences between cave beetles and humans would make any assumption of such a role difficult or impossible:

R012: $\quad$ The idea of feeling like an insect is very strange to me [laughs], so I think that they would have to put significantly more effort into that to really make me imagine that I feel like a cave beetle in this cave [laughs].

R016: $\quad$ Because we are deeply human inside, actually. It's hard and difficult to think differently... because we are used to being human.

As exemplified in the above, the establishment of a human perspective by the visitor to the exhibit is substantially, though unintentionally, supported by the exhibit's component parts and thus by the exhibit as a whole. In the following, the implications of this particular configuration of Biological Organization, Museographic Organization, and subsequent learning outcome are discussed with a view to elucidating patterns that may be generalised to a larger class of exhibit learning environments. 


\section{Discussion}

The aim of the present study was to study the embodiment of a body of knowledge as a means of supporting a certain learning outcome by connecting processes of its enactment to aspects of its design and thus back to the conjecture which drives the design. Specifically, the study deals with the claim that embodying the Biological Organization of the adaptations of the blind cave beetle to its environment of permanently dark caves with the Museographic Organization of an immersion exhibit can support the visitor learning outcome of experiencing how the cave beetle is adapted to its environment of permanently dark caves. After a brief discussion of some methodological issues, the main findings of the study regarding exhibit enactment, design, and conjecture will be discussed and their implications presented.

\section{Methodological Issues}

Studying visitor behaviour and vocalisations in a museum setting is logistically difficult due to variables such as the acoustics of the space, the ambient noise level, the movement and activity of the subject, and the various dynamics of other visitors (Allen, 2002). In the present study, the decision to observe single adult visitors primarily facilitated the chosen data collection method, but also served to control some of the variables. First, by fixing the audio capture equipment to the single subject being observed, the subject was never out of range of the microphone, a problem which would have been especially pertinent due to the walk-through nature of Cave Expedition if an attempt had been made to record group conversations. Second, the think aloud vocalisations of single adult visitors arguably included less of the fragmented and ambiguous discourse characteristic of groups of visitors (Allen, 2002) and could thus be coded more reliably.

The main limitation of investigating single adult visitors' interactions with and understandings of a museum exhibit is the issue of generalising the results to groups of visitors. Many studies emphasise the social nature of museum visits and the collaborative learning that takes place during such visits (e.g. Allen, 2002), an aspect of the museum visit that is absent from the analysis of the present study. On the other hand, the single adult is an existing museum visitor demographic (e.g. McManus, 1989) and thus also merits study. A potentially fruitful perspective could be to consider the observed praxeology of the single visitor as a baseline or first-order description of the exhibit's learning potential against which learning outcomes of group visits could be gauged. This would contribute to the understanding of exactly how the group dynamic influences the learning potential of an exhibit, and would be an interesting topic for a follow-up study. 


\section{Exhibit Enactment}

Although the intended learning outcome was not fully achieved by any of the respondents, it was partially achieved by a majority while a minority perceived the exhibit as a static display. This fundamental division corresponds well with two of the families of visitor reactions to immersion exhibits found by Belaën (2003), namely resonance and distance. In the resonance group, the visitors willingly surrendered themselves to the premise of the exhibit, immersing themselves in the representation and adopting the role assigned to them. These characteristics apply, as well, to the exhibit-rationalised-as-experience group who adopted the role assigned to them to the extent that they perceived it.

Likewise, the exhibit-rationalised-as-static-display respondents found in the present study may be characterised by those features that describe Belaën's distance category: these visitors figuratively, and sometimes literally, refuse to enter the immersion exhibit, deeming the staging disproportionate to the exhibited content. This distance-taking is caused by a gap between the visitors' expectations and the premise of the exhibition, but especially by the fact that these visitors do not grasp the meaning of the setting-in-space. The existence of this taxonomy of visitor reactions supports Belaën’s (2003) conclusion: that the Museographic Organization of immersion exhibits requires a certain ability in the visitor to decipher the language of the form, and that if the visitor does not have this ability, they are confused by the exhibit's premise.

Because immersion exhibits require a certain suspension of reality to function as intended (Belaën, 2005; Bitgood, 1990), the critical distance shown by the respondents in the exhibitrationalised-as-static-display group could be indicative of their failure or disinclination to use their imagination. Dufresne-Tassé et al. (2006) defined the term as 'psychological functioning where the intervention of the imagination can be observed' (author's translation) and found imagination to have a powerful motivating nature in museum exhibits, 'anchor[ing] the world of meaning created around the [exhibited] object within the visitor's experience and knowledge. It is a powerful agent of ownership of what is acquired in the exhibition' (Dufresne-Tassé et al., 2006, p. 172, author's translation). Dufresne-Tassé et al. estimated that 30-40\% of museum visitors use their imagination little or not at all during their visit, and argue that 'given the importance of an intense use of the imagination for a successful visit, it would be appropriate to intervene through the development of (...) exhibitions promoting its employment' (Dufresne-Tassé et al., 2006, p. 173, author's translation). The four recommendations made by these researchers to that end will be discussed in the following section on exhibit design. 
If a reluctance to use their imagination was the reason that the respondents in the exhibitrationalised-as-static-display group were not able to develop the intended technology, this was not the case with the respondents in the exhibit-rationalised-as-experience group. As shown in the preceding, the failure of these respondents to achieve the intended outcome was due to their perceptions of what, exactly, Cave Expedition as a whole was a representation of. When museum visitors are faced by an exhibit, they decide on the phenomenon or experience to be modelled in accordance with their own interpretive abilities (Falcão et al., 2004); lacking the means to decipher the exhibit as intended, they 'unconsciously apply the codes that apply to the deciphering of objects in the world familiar to them' (Bourdieu, 1969, p. 170, cited in Montpetit, 1996, p. 89, author's translation). Considering that the cave beetle environment represented by Cave Expedition is a world scarcely recognisable by humans (Howarth, 1983), it is not surprising that visitors substitute it with a familiar, human version of a cave environment. Moreover, as discussed in Mortensen (2009), the exhibit engineers themselves may have implicitly attempted to create a recognisable and thus anthropocentric world for visitors in order to ensure their comprehension. The implications of these coding and decoding issues for exhibit design will be discussed in the following section.

\section{Exhibit Design}

Two concerns with implications for exhibit design arose from the discussion of exhibit enactment, namely the rejection of the immersive premise of Cave Expedition's Museographic Organization by some respondents, and the unintended deciphering of the exhibit by other respondents. In the following sections, the three fundamental principles of immersion exhibits: the presentation of the exhibit as a coherent whole, the integration of the visitor, and the consequent dramatisation of matter and message (Belaën, 2003) will frame the discussion of the design implications of these visitor issues.

The presentation of the exhibit as a coherent whole.

As a scale version of a cave beetle habitat, Cave Expedition relies on a combination of two logics of representation: an exogenous logic, where the characteristics of the existing reference world of the cave beetle's habitat give rise to the characteristics of the exhibit; and an endogenous logic, where this reference world is reconstituted on a human scale (Mortensen, 2009). Exhibits of this type run an increased risk of excluding those visitors who cannot decipher the form, as was indeed the case here with the respondents who rationalised Cave Expedition as a static display. Such exhibits accordingly require mediation that can assist the 'first degree' perception of the exhibit 
(Belaën, 2005). This suggestion converges with the first recommendation of Dufresne-Tassé et al. (2006): introduce the exhibit so that visitors can easily use their imagination to establish a first link between what the exhibit offers and their own experience or knowledge. In other words, the metaphor employed in the exhibit should be made explicit - in the present case, the nature of the exhibit as an animal habitat should be clarified and the scaling made obvious in a manner which links to the visitors' prior knowledge.

The respondents who rationalised the exhibit as an experience appeared to have no trouble with the first degree perception of the exhibit as an immersive cave environment, albeit from a human perspective. The human perspective incorporated into the exhibit design was found to originate in the exhibit development, at a point where processes of physically implementing the exhibit took over from processes of developing the biological content (Mortensen, 2009). This phase of development may be particularly vulnerable to a lessening of epistemological vigilance due to technical issues, costs, or the desire to employ exhibit styles that have proven popular. When this is the case, the further development of the exhibit tends to ignore the scientific discourse in favour of visual and spatial logic (Gouvêa de Sousa et al., 2002), and as a consequence, visitors’ conceptions of the exhibit's content may reflect those of the exhibit engineers rather than those of scientists (Van-Praët, 1989). In the present case, the relaxation of epistemological vigilance in the exhibit design process had direct consequences for visitor outcomes; consequences that meant that the intended visitor learning outcome was not achieved.

On one hand, it is understandable that exhibit engineers, when dealing with the reconstruction of an environment which is difficult for humans to conceive of, take recourse in reconstructing a related environment which most visitors presumably are able to decipher. On the other hand, it could be argued that it is the finest challenge of exhibit engineers to not shy away from difficult subject matter, but to embrace it. Indeed, Dufresne-Tassé et al. (2006) emphasise the importance of designing an exhibit in ways that are novel to the visitor in order to engage their curiosity; this recommendation tends to encourage a pushing of the museographic boundaries towards new innovative forms. The challenge here is accordingly to not only re-create the cave beetle's environment in an immersive exhibit with fidelity towards the original, but to do so in a way which communicates precisely and coherently what is on display.

The integration of the visitor.

Cave Expedition did not succeed in integrating the visitors as intended. Although in some cases the exhibit did promote a sense of an authentic cave setting and ambience among the visitors 
and thus achieved a low level of visitor integration (cf. Belaën, 2003), it failed to do so in other cases where it was perceived merely as a decoration or backdrop for the content on display. What are the design implications of these shortcomings?

The point raised by some visitors that human beings and cave beetles are vastly different organisms with little or no commonality seems to provide at least a partial explanation for why the visitors did not perceive and step into their intended roles as cave beetles. However, role-play in formal science education contexts includes students successfully playing the roles of red blood cells or electrons (Aubusson et al., 1997); entities that arguably have less in common with human beings than cave beetles do. The reason visitors do not comprehend their intended role probably originates elsewhere, namely in the insufficiency of the cues intended to provide them with this information and the means to implement it.

A basic design strategy to achieve a successful integration of the visitor in the exhibit could be to redirect the initial interest of the visitor from the exhibit's content to its participatory form (Belaën, 2005). Once the experiential nature of the interaction-to-come has been unequivocally established, the visitor should be given tools to implement their role. Aubusson et al. (1997) discuss the requirements for the successful implementation of role-playing in a classroom context: 1) introduce the target concept, 2) cue students' memory to the analogy, 3) identify the relevant features of the analogy, 4) map the similarities between the analogy and the target (science subject matter), 5) indicate where the analogy breaks down, and 6) draw conclusions about the target concept. Applying these requirements to an immersion exhibit context yields the following recommendations: 1) introduce the visitor to their intended role, 2) cue the visitor to the situation they are about to experience, 3) identify the relevant features of the immersive exhibit in terms of the visitor's role, 4) map the similarities between the visitor's experience and the scientific content, 5) indicate where the analogy breaks down, and 6) draw conclusions about the target concept. It could be argued that Cave Expedition already fulfils some of these requirements, but in a manner too subtle for the visitors to detect. A systematic and concrete embodiment of some or all of the suggestions would presumably assist the visitor in assuming the intended cave beetle role. One example of identifying the relevant features of the immersive cave environment in terms of the visitor in their role of the cave beetle could entail making the visitor aware that the cave beetle lives in complete darkness, and that the visitor must navigate the darkened cave exhibit using mainly their sense of touch - just like the cave beetle. 


\section{The dramatisation of matter and message.}

In addition to the museum visitor understanding and taking on their role as the main character, the degree to which the subject matter of an immersive exhibition is dramatised depends on the degree to which the conflicts of that character are made clear to them, the degree to which the surroundings allow them to act on that conflict, and the degree to which they are able to make sense of these actions in terms of a direction (cf. Damiano et al., 2005). In the present case, visitors did not interpret the conflicts (e.g. the presence of predators in the form of the animal models in the cave) of their character as intended and consequently were not able to act on those conflicts and make sense of these actions to create a narrative about the cave beetle in the intended way. What are the design implications of these shortcomings?

In media such as film or literature, narratives are conceived of as entire dramatic structures comprised by a beginning, middle, and end. However, when the narrative is not fixed but rather emergent through a user's interactions with a three-dimensional environment, incorporating drama at each moment of the narrative may be a better way to create engagement (Macfadyen et al., 2008); a finding which coincides with Allen's (2004) recommendation that museum exhibits be motivating at every intermediate step of the visitor's experience, not just at the culmination. The immersion exhibit should accordingly act as an imaginative space which creates a desire to discover a new world, and which can be used constructively by visitors to explore this world (Dufresne-Tassé et al., 2006). To this end, Dufresne-Tassé et al. emphasise the importance of conducting a thorough formal contextualisation of the exhibit topic in the development phase in order to give the topic sufficient depth. In Cave Expedition, a possible design implication of the findings mentioned above could be for the exhibit to reflect the complexity of the body of knowledge in question (the cave beetle's daily struggle for survival in its habitat) rather than a series of anticipated trajectories of inquiry represented by a sequence of stations, as is perhaps the case now. The idea would be that the visitor, when they entered the exhibit, would not merely be thrown into darkness (which is one aspect of cave beetle reality) but be thrown into the entire complexity of the cave beetle habitat. Such an exhibit would form a framework sufficiently strong, dense, and consistent that the visitor's imagination could be constructively supported to clarify the content matter in ways that are meaningful to them (Dufresne-Tassé et al., 2006), which would especially address the issue of the visitors who perceived Cave Expedition as a static display. 


\section{Exhibit Conjecture}

In retrospect, it is not surprising that the reasons for differences between intended and observed visitor outcomes should be sought at the level of the exhibit rather than at the level of its component parts: the Museological Organization of Cave Expedition embodies a human perspective of a cave environment, and the visitors' accommodation of this perspective, while unintended, substantiates the premise that the exhibit constitutes a learning ecology which is perceived as a whole (cf. Cobb et al., 2003). This observation in turn emphasises the importance of making a wellinformed choice of exhibit type (or Museographic Organization) when a subject has been decided upon in the exhibit planning phase. As there is no exclusive museographic form for specific themes, although some subjects have characteristics that are more or less suitable to a particular exhibit type (Gouvêa de Sousa et al., 2002), matching the Biological (or other) Organization and the corresponding learning goals to the Museographic Organization becomes an all-important undertaking if exhibit engineers are serious about achieving educational objectives.

In this light, the conjecture that embodying the Biological Organization of the adaptations of the blind cave beetle to its environment of permanently dark caves with the Museographic Organization of an immersion exhibit can support the visitor learning outcome of experiencing how the cave beetle is adapted to its environment of permanently dark caves seems to be a reasonable one. Although the stated goal of the exhibit - the intended praxeology - was not achieved by the museum visitors, it was partially achieved by a majority of respondents. Immersion exhibits are vehicles of experience, and although the experiences of the visitors observed here were shown to diverge from the intended experience, the exhibit showed clear potential in the direction of creating the intended experience.

\section{Conclusion}

The present study examined in detail how an immersion exhibit works, i.e. how it mediates its message to museum visitors. The notion of praxeology allowed the study to pinpoint not only how and why divergences between intended and observed learning outcomes occurred, but at which level of the Museographic Organization they originated. As a consequence, the exhibit characteristics at the origin of the divergences could be examined, and theoretical suggestions for remedial design formulated. It is beyond the scope of this paper to construct a theoretical model for the design of immersion exhibits; however, some generalisable suggestions were given, i.e.: An immersion exhibit which employs a metaphorical representation of a reference world requires the 
metaphor to be apparent to the visitor without sacrificing scientific rigour. The participatory nature of the immersion exhibit should also be made explicit; role-play guidelines may be useful in this regard. Finally, it is important to conduct a thorough contextualisation of the exhibit's scientific content in the development phase in order to achieve a sufficiently strong and consistent framework which can successfully support the interactive visitor-exhibit dramatisation of the subject matter.

These rather general suggestions assume their full meaning when implemented with a concrete scientific content. It is clear, though, that exhibit design may benefit from an approach that considers both practical and theoretical aspects such as the praxeology-based approach exemplified here. A follow-up study is currently under way which uses the notion of praxeology to synthesise a coherent and broadly applicable theoretical framework to guide the didactical design of immersion exhibits.

\section{Cited Literature}

Allen, S. (2002). Looking for learning in visitor talk: a methodological exploration. In G.Leinhardt, Crowley, K., \& Knutson, K. (Eds.), Learning conversations in museums (1 ed., pp. 259303). Mahwah, New Jersey: Lawrence Erlbaum Associates.

Allen, S. (2004). Designs for learning: studying science museum exhibits that do more than entertain. Science Education, 88(Suppl. 1), S17-S33.

Alt, M. B. \& Shaw, K. M. (1984). Characteristics of ideal museum exhibits. British Journal of Psychology, 75, 25-36.

Aubusson, P., Fogwill, S., Barr, R., \& Perkovic, L. (1997). What happens when students do simulation-role-play in science? Research in Science Education, 27(4), 565-579.

Barquero, B., Bosch, M., \& Gascón, J. (2007). Using research and study courses for teaching modelling at university level. In M.Bosch (Ed.) Proceedings of the V Congress of the European Society for Research in Mathematics Education (CERME 5), (pp. 2050-2059). Barcelona

Belaën, F. (2003, September). L'analyse de l'apparition d'un nouveau genre culturel dans les musées des sciences: les expositions d'immersion. Paper presented at the International Cultural Heritage Informatics Meeting, Paris, France. 
Belaën, F. (2005). L'immersion dans les musées de science: médiation ou séduction? Culture \& Musées, 5, 91-110.

Bitgood, S. (1990). The role of simulated immersion in exhibition (Rep. No. 90-20). Center for Social Design, Jacksonville, Alabama, USA.

Chevallard, Y. (1999). L'analyse de pratiques professorales dans la théorie anthropologique du didactique. Recherches en Didactique des Mathematiques, 19(2), 221-266.

Chevallard, Y. (2007). Readjusting didactics to a changing epistemology. European Educational Research Journal, 6(2), 131-134.

Cobb, P., Confrey, J., diSessa, A., Lehrer, R., \& Schauble, L. (2003). Design experiments in educational research. Educational Researcher, 32(1), 9-13.

Damiano, R., Lombardo, V., \& Pizzo, A. (2005). Formal encoding of drama ontology. In G.Subsol (Ed.), Virtual Storytelling (pp. 95-104). Berlin: Springer-Verlag.

Dufresne-Tassé, C., Marin, S., Sauvé, M., \& Banna, N. (2006). L'imagination comme force dynamisante du traitement des objets muséaux par des visiteurs occasionnels [Imagination as a motivating force in visitors' apprehension of museum objects]. In C. Dufresne-Tassé (Ed.), Families, schoolchildren and seniors at the museum: Research and trends (pp. 160176). Québec, Canada: Éditions MultiMondes.

Executive Committee (2005). Xtremes: storyline for an exhibition about adaptations to extreme environmental conditions on Earth. Experimentarium, RBINS, Naturalis.

Falcão, D., Colinvaux, D., Krapas, S., Querioz, F. A., Alves, F., Cazelli, S. et al. (2004). A modelbased approach to science exhibition evaluation: a case study in a Brazilian astronomy museum. International Journal of Science Education, 26(8), 951-978.

Gouvêa de Sousa, G., Valente, M. E., Cazelli, S., Alves, F., Marandino, M., \& Falcão, D. (2002). A study of the process of museographic transposition in two exhibitions at the MAST (Museu de Astronomia e Ciências Afins). In C. Dufresne-Tasse (Ed.), Evaluation: multipurpose applied research (pp. 108-124). Québec: Éditions MultiMondes. 
Guichard, J. (1995). Designing tools to develop the conception of learners. International Journal of Science Education, 17(2), 243-253.

Henderlong, J. \& Paris, S. G. (1996). Children's motivation to explore partially completed exhibits in hands-on museums. Contemporary Educational Psychology, 21, 111-128.

Howarth, F. G. (1983). Ecology of cave arthropods. Annual Review of Entomology, 28, 365-389.

Macfadyen, A., Stranieri, Andrew, \& Yearwood, John L. (2008, August). Dramatic level analysis for interactive narrative. Paper presented at the 5th International Conference on Narrative and Interactive Learning Environments, Edinburgh, Scotland.

McManus, P. (1989). Oh, yes, they do: how museum visitors read labels and interact with exhibit texts. Curator, 32(3), 174-189.

Meisner, R., vom Lehn, D., Heath, C., Burch, A., Gammon, B., \& Reisman, M. (2007). Exhibiting performance: co-participation in science centres and museums. International Journal of Science Education, 29(12), 1531-1555.

Mortensen, M. F. (2009). Museographic transposition: The development of a museum exhibit on animal adaptations to darkness. Manuscript submitted for publication.

Montpetit, R. (1996). Une logique d'exposition populaire: Les images de la muséographie analogique. Publics \& Musées, 9, 55-100.

Moscardo, G. (1996). Mindful visitors: heritage and tourism. Annals of Tourism Research, 23(2), 376-397.

Robinson, V. M. J. (1998). Methodology and the research-practice gap. Educational Researcher, 27(1), 17-26.

Rodríguez, E., Bosch, M., \& Gascón, J. (2007). An anthropological approach to metacognition: the "study and research courses". In M.Bosch (Ed.) Proceedings of the V Congress of the European Society for Research in Mathematics Education (CERME 5) Barcelona

Sandoval, W. A. (2004). Developing learning theory by refining conjectures embodied in educational designs. Educational Psychologist, 39(4), 213-223. 
Schauble, L. \& Bartlett, K. (1997). Constructing a science gallery for children and families: the role of research in an innovative design process. Science Education, 81, 781-793.

The Design-Based Research Collective (2003). Design-based research: an emerging paradigm for educational inquiry. Educational Researcher, 32(1), 5-8.

Tulley, A. \& Lucas, A. M. (1991). Interacting with a science museum exhibit: vicarious and direct experience and subsequent understanding. International Journal of Science Education, 13(5), 533-542.

van Someren, M. W., Barnard, Y. F., \& Sandberg, J. A. C. (1994). The think aloud method: A practical guide to modelling cognitive processes. London: Academic Press.

Van-Praët, M. (1989). Contradictions des musées d'histoire naturelle et évolution de leurs expositions. In B. Schiele (Ed.), Faire voir, faire savoir - la muséologie scientifique au présent (pp. 25-34). Québec: Musée de la Civilisation.

\section{Appendix A}

The Questions Developed in the Pilot Study

1. What is it supposed to be, the exhibit you were just exploring? (practical level)

2. What makes it a [answer from 1]? (theoretical level)

3. Did you notice anything (else) when you entered? (practical level)

4. How did you find your way, inside? (practical level)

5. What was inside/what did you find, inside? (practical level)

6. (If "animals” then) Why do you think those particular animals were there? (theoretical level)

7. Did you use your other senses, inside? (practical level)

8. What is the point of this exhibit? What are you meant to learn from it or do with it? (theoretical level)

9. Is this exhibit about any particular animal? (theoretical level) 


\section{The Additional Questions}

1. This exhibit is about the blind cave beetle and its adaptations to its habitat. If you imagine yourself in the role of the cave beetle, or if you think about your experience in the exhibit in terms of being a cave beetle, what does this exhibit tell you about cave beetles?

a. How do they find their way in the dark?

b. What are their most important senses?

c. What is their environment like?

d. What other animals might they encounter in their environment?

2. Why did you not feel that you were a cave beetle in this exhibit? What aspects of this exhibit could be changed to make you, the visitor, feel like a cave beetle?

\section{Footnotes}

1. The term design is used in this paper to indicate the pedagogical and didactical engineering of an educational intervention such as an exhibit. 